\title{
Drought and Desalination: Melbourne water supply and development choices in the twenty-first century
}

\author{
Michael G. Porter*, David Downie, Helen Scarborough, Oz Sahin, Rodney A. Stewart \\ Deakin University City Centre, 3rd Floor, 550 Bourke St., Melbourne 3000, Australia, Tel. +61 35227 8424; \\ email: michael.porter@deakin.edu.au
}

Received 16 April 2014; Accepted 16 June 2014

\section{ABSTRACT}

Sharply reduced catchment inflows across Australia around the end of the twentieth Century $y_{\Lambda}$ led to a sequence of water restrictions followed, as the drought persisted, by approximately $\$ 10$ billion of investments in desalination plants near Perth, Adelaide, Melbourne, Sydney and Brisbane. This Deakin University project jointly with Griffith University, for the National Centre of Excellence in Desalination (NCEDA), follows these new investments. We ask how best to manage bulk water supply and retail supply given the facts and fears of uncertain rainfall, modelled over a 100 year simulation period. We use Monte Carlo style studies aiming to capture the new tensions and trade-offs regarding uncertain climate, rainfall and water supply. There are presently no comprehensive life-cycle approaches to model city water balances that incorporate economic feedbacks, such as tariff adjustment, which can in turn create a financing capacity for such investment responses to low catchment levels, models that could provide significant policy implications for water planners. This project addresses the gap, and presents excerpt from a system dynamics model that augments the usual water utility representation of the physical linkages and water grids. We add inter-connected feedback loops in tariff structures, demand levels and financing capacity. Tariffs are reset in association with drought and the modelling of responses both in terms of reduced consumption and increased revenue of the utility, depending on the elasticity's of demand responses to higher tariffs, both short and long term, while also allowing

${ }^{*}$ Corresponding author.

This research is part of a project, Desalination and Drought in Australia-the Bigger Picture, undertaken for the National Centre of Excellence in Desalination in Australia (NCEDA) and funded by a grant from NCEDA to Professor Michael Porter at Deakin University. The project is led jointly with Associate Professor Rodney Stewart of the Smart Water Research Centre at Griffith University, with technical cooperation from AECOM Ltd. This paper is one in a sequence of studies on desalination across Australia. It focuses on differing water grids, pipelines, storages, diversions and networks of bulk supply sources, supplemented by potential and actual trading relationships. The authors acknowledge the excellent research assistance of Sarah Hilborn and Zohidjon Askarov and the text editing of Eliza Spring.

Presented at the Conference on Desalination for the Environment: Clean Water and Energy 11-15 May 2014, Limassol, Cyprus 
effects from any transitional restrictions. Before reporting on parts of the simulations applied to Melbourne, this paper will first review the general issues surrounding whether desalination is or can be a "game changer" for economic development that hinges on secure water supply. We then explore options in bulk water supply management when desalination augments the choices, including catchments, dams, recycling, pipelines from rivers and savings in irrigation. Finally, the paper addresses the intriguing and important question of the value and cost of providing water for environmental uses.

\section{1. Introduction}

This paper discusses the role and value of desalination in water grids, relative to dams and catchments, given uncertain rainfall and resulting inflows to catchments. We also discuss, but do not

20 relax, current political restrictions on the use of pipelines between river catchments. We project some preliminary results of "desalination versus dams" cost comparisons within bulk water systems using an augmented system dynamics model for metropol-

25 itan Melbourne applied to historical inflow data over a century. Through these simulations we discuss how desalination, through reverse osmosis, fits in south-eastern Australia across a bulk water grid $^{1}$ simulated over 100 years of rainfall

30 variations.

Recent cost reductions in reverse osmosis have made desalinated water affordable relative to evaporative techniques. ${ }^{2}$ Desalination also lowers water costs by tens of billions of dollars over the century

35 ahead by ending the need for water restrictions, the modular nature of reverse osmosis and avoiding dams. This paper and other studies in the NCEDA project demonstrate for cities within "dry" countries such as Australia, Israel, Chile, Saudi Arabia, the

40 west of the United States and the United Arab Emirates (all with reasonable access to oceans) desalination is a potential game changer for economic and population growth.

Desalinated water in the twenty-first century is a 45 liberating opportunity for water-dependent metropol-

\footnotetext{
${ }^{1}$ This paper refers to "Eastern Australia" rather than just Victoria, as the Victorian grid around Melbourne is a substantial network, linked to the Murray-Darling Basin and with the potential to form a real market for water trading that covers three states, with potential variations in supply-demand balance in each state being improved through the sharing and trading of water. Adelaide, for example, draws heavily on the River Murray $(91 \%$ of demand in AQ3 2007 [1]), and the potential for interconnection in New Bouth Wales is real via the Shoalhaven River.

See [2] for a review of cost trends of desalination with the advent of reverse osmosis.
}

itan and agricultural communities. While Australia has already demonstrated and benefited from globally advanced use of markets and water trading, adding desalination brings new levels of security and benefits from trading, reduces economic and social risk from water shortages. The same is true in global water markets and will depend on reforms to water institutions to facilitate efficient and affordable water use where it is most valued.

For communities with well-defined water rights and entitlements to share, trade and use water, a new rainfall-independent supply source delivers a lower risk level both for water supply and economic development at given water cost levels. The precise degree of reduction in water risk that can be afforded depends on the fixed and variable costs of substituting desalination for other water supply sources in the grid, including new dams, recycled water and groundwater. Our model focuses on these costs and network issues, and confirms that trading institutions and modular expansion are the keys to get water to the users that value it the most.

Industries that can expand using an optimised grid including desalinated water supply depends not just on water catchments, treatment, irrigation and distribution costs, but on general economic efficiency in agriculture and other industries. The purposes of AQ4 water investments are many, ranging from delivering the fundamental requirements for life to irrigation and sustaining our economic systems. The total value of water far exceeds costs ${ }^{3}$ and depends on many other things. The problem in moving to traded solutions is that water is perhaps the least homogenous of all economic commodities, making the application of market economics more complicated. But with smart sensors and measurement

\footnotetext{
${ }^{3}$ The famous economics 101 question is: "What is more valuable, water or diamonds?" The it depends answer requires understanding of average versus marginal values: too little water we die, too much we drown; whereas diamonds are different and could not buy water if dying in a desert.
} 
capacity for both quantity and quality, water can be efficiently produced and used. Governments need to allow (and not suppress) the incentives for markets, pricing, costing and trading water. The income and wealth facilitated by secure access to water will readily finance assistance and rebates under the emerging price structures, as even casual international comparisons make clear.

Because of its essential nature, metropolitan and regional water supply policy has generally fallen to government agencies. However, political pressure means water is often under-priced because it appears free in nature and for affordability reasons. ${ }^{4}$ Yet water is far from free to deliver, treat, store or secure. While not challenging the policy and assistance roles for government, we note that including desalination in the water grid provides the scope for real water markets and efficiencies through trading and pricing via private investment. Further, desalination is a form of water insurance across the grid that can deliver water security.

Our discussion illustrates how the institutions and markets for water, including desalination, are of central relevance to the well-being of all communities, not just those near the sea, once water security across a grid becomes reality. And as flagged above, we also show how trading and desalination, by reducing the number of dams necessary for a level of water security, can reduce capital and average costs over the long term by increasing security. While there are simple rules of thumb-such as multi-part pricing for access and usage by season, volumetric marginal cost pricing in the short run, and rules that aid funds and investment-the volatility of rainfall and its geographical distribution make pricing a complex matter suited to markets

\footnotetext{
"The fact water can be "free" from nature including the skies, land and sea, is a small and potentially misleading part of the story, since the access and usage payments of households, farms and corporations are for "everything else" about water in order that it be potable, safe and delivered conveniently. In general, pricing water at near zero levels or way below cost recovery levels is a sure way of preventing extension of water services, creating water scarcity and often poverty rather than equity. The pricing of water, usually with low charges for the first $100 \mathrm{~L}$, but substantially more for the successive blocks, is an important subject in itself. Suffice it to say at this point, that when we take a long run perspective, when water is priced at very low levels so that consumption is wasted and production incentives inadequate, the resulting scarcity makes water in fact very expensive to obtain when needed-causing high marginal costs of the next source, such as trucks or personal carrying.
}

that can package options and differential scarcity by season and cost. ${ }^{5}$

Treating water as a scarce economic commodity that is volatile over time is a crucial starting point for enabling water markets to assist, rather than hinder, economic development. Similarly, adding modular and expandable desalinated options is an insurance buffer; it assists, otherwise, risky and insecure waterdependent industries. Well-structured desalination reduces supply risk and, importantly, may also lower the cost of capital if the capital market is well informed and enables production of premium water-intensive products, as currently exemplified in Israel. ${ }^{6}$

${ }^{5}$ In general, an extra unit of water at point $X$ should reflect the marginal cost of getting water to $X$, which may often be very low. But the investment has to be funded, average costs covered. One way of handling this fixed cost element is an access charge, with the sum of access charges being a mechanism for recouping the fixed cost of catching, storing and distributing water at point $X$. Such rules of thumb are useful, and amending them to assist in funding desalination plants is a question of interest. But these pricing signals also need to be reflective of expected future real costs of obtaining extra water. The general rule favours multipart tariffs and options trading. The first or access charge should be that charge necessary to secure financing of investment in water supply and piping water to people over the asset's life. Tariffs for water above some very modest minimum need to be high enough to signal the need to economise consumption and produce substitutes. Pricing water at very low levels in water supply systems both neglects long run marginal costs and the importance of sending signals to other potential suppliers of water, for example desalination, that make them willing to invest. However, investment requires long-term funds, and thus we are led to support much higher prices to cover long run marginal costs of provision. Where these tariffs are unaffordable to low income people the case is strong for helping them directly with rebates or supports, but not by suppressing prices. Where supply is inefficient, prices need to be high enough to induce entry. But new entry is hard to achieve given the absent real markets or with government provision well below average cost.

${ }^{6}$ Israel like Australia was a pioneer of water-saving drip irrigation, and both countries are active in fertigationjoint optimisation of fertiliser use and irrigation. "Fertigation" in Israel and the use of smart software for decision support for agriculture would seem to explain the prevalence of high valued-added production and exports of fruit and vegetables relative to Australia and the US for example. According to [3], the prices of desalinated water in Israel are as low as US $\$ 0.52$ per $\mathrm{M}^{3}$, substantially below costs in Australia where dependent on environmental, distance, capital and energy costs, desalinated water has varied between $\$ 1.30$ around $\$ 1.50$ per $\mathrm{M}^{3}$. Thus, while desalinated water and treated wastewater are widely used in premium fruit and vegetables in Israel, to-date costs of desalination in Australia make agricultural use uneconomic relative to the use of relatively abundant river water.
40 
The modular and compact nature of desalination investments, as opposed to river-driven and landintensive catchments, deliver beneficial savings over time as secure land catchments become scarce relative to land needed for ocean access. Because desalination and other technologies are typically researched from engineering schools, this paper stresses the economic dimensions often left aside by technical experts.

Section 2 of this paper provides an overview of the 10 Wonthaggi desalination decision. Section 3 looks at the broad issues associated with desalination and contemporary water supply in Australia and beyond. Section 4 brings together the preceding discussions and presents our preliminary results for Melbourne.

\section{2. Desalination: the Australian context}

\subsection{The millennium drought: Desalination investments for five Mainland cities}

The Millennium Drought in southeast Australia between 1997 and 2009 was the worst in recorded history [4]. At its peak, five state governments sought to augment water supplies via large-scale desalination. As noted in the Climate Council of Australia's March 2014 report and in Fig. 1 below, rainfall patterns have moved in Australia, perhaps as a consequence of climate change. $^{7}$

Through these new desalination investments, Australia added water insurance to an abundant total per capita rainfall-albeit extremely uneven across the continent, as shown. While rainfall levels have generally returned to normal in 2014 (but not in western Australia and some rural areas of New South Wales, Victoria and Queensland), the lower marginal costs of desalinated water still challenge other sources as new dams and catchments are nearly impossible to secure or finance. Consequently, desalination has changed the dynamics of investment in water supply across Australia, as environmental pressures mean we increasingly favour more compact and modular water sources independent of rainfall. In principle, recycled wastewater and treated stormwater should be options, but it has generally been unpopular with communities due to costs and viral and associated

\footnotetext{
${ }^{7}$ Ref. [5] stated, "Southwest Australia has experienced decreases in autumn and winter rainfall since the 1970s, and the southeast has experienced decreased autumn and winter rainfall since the 1990s. Increased drought frequency is expected in southern Australia, with decreases in the amount of rainfall by as much as $10 \%$ by 2030 , and by up to $30 \%$ by $2070^{\prime \prime}$.
}

health fears. Capturing stormwater and tanks also have some controversial acceptance politically, but high unit costs, the absence of scalability, and the correlation of storms with rainfall mean that option has been set aside.

\subsection{The Wonthaggi desalination decision}

In 2007, the Victorian government led by Premier Steve Bracks announced a $\$ 4.9$ billion package to secure water supplies in Victoria. It included a 150 GL/pa desalination plant, located at Wonthaggi $85 \mathrm{~km}$ from Melbourne. Other water investments were an expansion of the grid in the Goulburn region and a pipeline to Melbourne from the Goulburn River (see Extract 1). The water augmentation decisions were taken as citizens endured severe water restrictions and storage levels in Melbourne's dams reached critically low levels (28.5\% in June 2007). ${ }^{8}$ The average inflow between 1997 and 2009 was 376 GL/pa, compared with 615 GL/pa between 1913 and 1996 (see Fig. 2). Extrapolations undertaken by [6] in 2007 of the last three years of diminishing inflows frightened the Victorian Government and community [6]. The subsequent Premier and former Treasurer, John Brumby, reflected at a desalination conference held by the NCEDA at Australia in November 2013 [7]. which-in his view was-a smaller $50 \mathrm{GL} / \mathrm{pa}$ plant or a negative decision on desalination were not options for a responsible Government given the larger scale economies and the prospect of continued record-breaking drought.

The rain since 2007 and some floods ended the drought with a vengeance. The decision to build a $150 \mathrm{GL} / \mathrm{pa}$ plant (expandable to $200 \mathrm{GL} / \mathrm{pa}$ ) on 263 hectares at Wonthaggi, led to what was the largest desalination plant in the world at the time (since replaced in 2014 by a 150-200Gl plant in Sorek, south of Tel Aviv, in Israel). ${ }^{9}$ The Wonthaggi plant, while receiving technical awards, remains controversial, not least because it is $85 \mathrm{~km}$ from storages (greatly inflating pumping costs to the city).

What is particularly interesting in terms of our simulation of costs of desalination vs. dams is that the catchments of the Melbourne system centre on the massive Thomson Dam with 1,000 Gl of storage. The dam is served by huge restricted public and private

\footnotetext{
${ }^{8}$ As at 14 June 2007 [6].

${ }^{9}$ For a summary of the most extensive national usage of desalination see [3].
} 


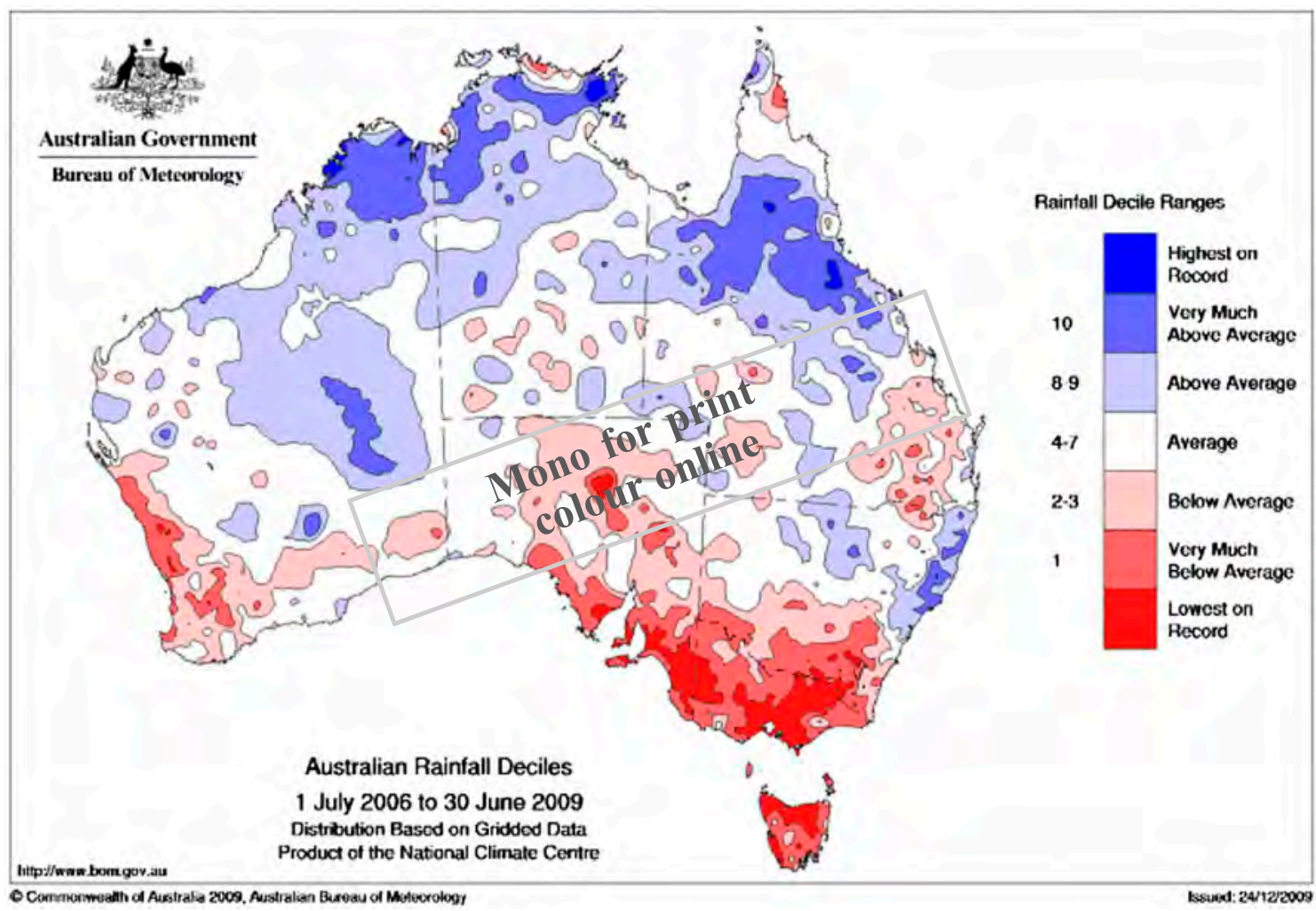

Fig. 1. Rainfall in Australia, 1 July 2006-30 June 2009 [26].

catchments of 156,700 hectares, ${ }^{10}$ compared with 263 hectares for Wonthaggi and its $150 \mathrm{GL} /$ pa capacity. We find that, as land and catchment prices escalate in the next century, desalination-with its greatly reduced land requirements-becomes by far the cheaper source of rainfallindependent bulk potable water.

Desalination costs will typically fall relative to raindependent water because the relative cost of catchments and dams will escalate sharply over the coming decades as the economy and population expand. The relative capital cost of dams to desalination could rise to a factor of four or five over the next century (see Fig. 7 below), given a modest price escalator for land of $1 \%$ per annum. A factor working against the relative cost advantage of desalination, of course, could be the energy costs of pumping water through mem-

\footnotetext{
${ }^{10}$ Melbourne Water advises that these catchments comprises about 56,300 hectares of state forest, managed by the Department of Environment and Primary Industries (some have limited public access while others allow activities like camping, four wheel driving and logging); 90,800 hectares of national park, managed by Melbourne Water and Parks Victoria under agreement (most are off-limits to the public and allow only limited activities such as bushwalking); 7,500 hectares of Melbourne Water land and 2,100 hectares of private land [8].
}

branes, with the laws of physics showing that it takes a theoretical minimum of about $1 \mathrm{kWh}$ per cubic metre of desalinated water [9] with the current best practice figure around $2 \mathrm{kWh}$.

\subsection{The Victorian water grid}

In Victoria, water entitlements and volumes can be piped and traded and, despite some opposition, a sophisticated bulk market is developing. It is assisted by companies such as Waterfind, ${ }^{11}$ within a market that extends to Victoria, South Australia and New South Wales, and draws water from aquifers extending as far north as Queensland. As evident in an earlier DSE planning map of the Victorian Water Grid in 2007 (see Fig. 3), substantial existing interconnections and new pipelines make virtual and physical water trading eminently feasible across much of south-eastern Australia. For example, Lake Eildon on the Goulburn River has about 3,300 GL capacity, more than twenty times the annual production capacity of the desalination plant at Wonthaggi. This suggests that, as an element of the Victorian Water Grid, the

\footnotetext{
${ }^{11}$ See: www.waterfind.com.au.
} 


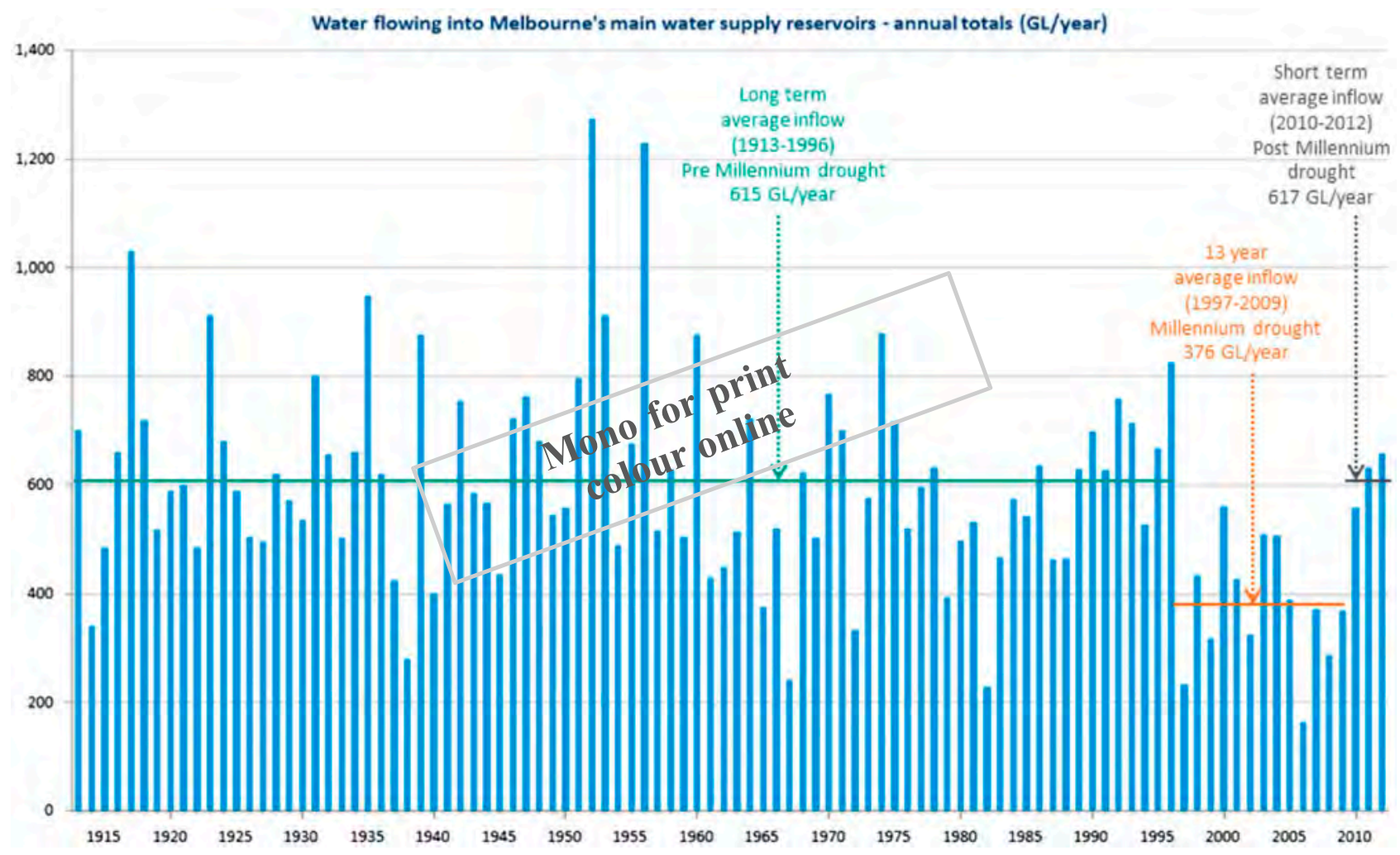

Fig. 2. Yearly inflows into Melbourne's water supply reservoirs 1913-2012 [25].

5 Goulburn River and storages are highly valuable, despite rainfall dependence.

Prof. Briscoe of Harvard University, Langford and Porter [10] noted that the water trading in Australia in the Millennium Drought sustained farm incomes despite variations around $70 \%$ reductions in rainfall. ${ }^{12}$ In his critical submission to the Senate inquiry into the provisions of the Commonwealth Water Act 2007 and the management of the Murray-Darling Basin, Prof. Briscoe [11] stated, "this extraordinary achievement is, in my view, the single most important water fact of the twenty-first century, because it shows that it is possible (with ingenuity and investment) to adapt to rapid climate change and associated water scarcity". Further, water management policies in Australia did

\footnotetext{
12“Unlike most of our food exporting competitors, our major population centres are largely coastal and have water insurance in terms of desalination plants. So our food bowls need not be drained by the cities and can implement a wide range of productivity enhancements. Hence, water is not a rigid constraint on either our population or our production. Our relative situation has been helped by innovations such as trading of water rights, pricing reforms and the development of water grids. And the relative price of food is likely to rise more than these costs, creating advantages for agricultural exports" [10].
}

something that "no other country could conceivably have managed-in a large irrigated economy (the Murray-Darling Basin) a 70\% reduction in water availability had very little aggregate economic impact".

The difficulty with trading and pipelines is that the farm community and some politicians doesn't yet fully comprehend the value to buyers and sellers of shifting water across catchments. However, increasingly farmers are learning that trading water can be no less rewarding than trading farm output. Many are now aware that during the drought the trading of bulk water by pipeline and the sale of water abstraction rights enabled farmers to sustain their incomes.

The other widely misunderstood dimension is just how much water trading involving in the MurrayDarling Basin Rivers is a part of the solution to water scarcity. Just as dams such as the Thomson have vast potential, although stretched by low inflows leading up to 2007, so too do the rivers like the Goulburn and the Eildon Dam. Statistical evidence is clear from the Northern Victoria Irrigation Renewal Project (NVIRP) scheme (Stages 1 and 2). Irrigators agreed to save and trade water in exchange for irrigation upgrades funded partly by governments, with the Commonwealth and the State of Victoria gaining substantial allocations for environmental purposes. 


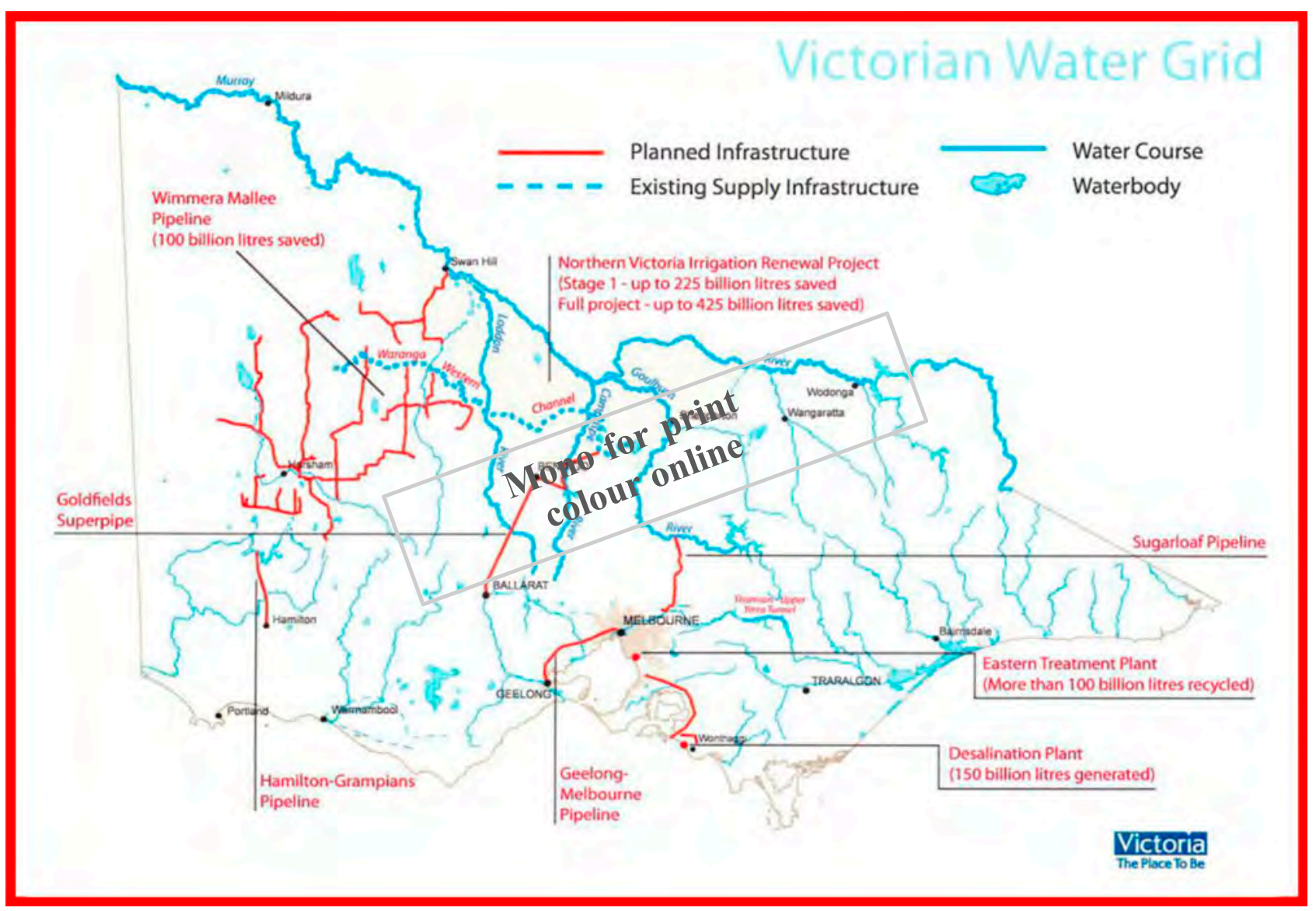

Fig. 3. The Victorian water grid (DSE 2009).

The Australian Government supported NVIRP and contributed over $\$ 956$ million and Victoria \$106 million to Stage 2 of NVIRP [12] ${ }^{13}$. Stage 2 aims to generate $200 \mathrm{GL}$ of water savings to be split between the Commonwealth and Victoria, comparable to the production of desalinated water from the Wonthaggi plant. The heart of the proposal is enhancing the trade of potential irrigation waters, with savings for "the environment" (that is rivers, aquifers and general uses beyond agricultural activity) going into recreational and other areas according to relative scarcity. ${ }^{14}$

${ }^{13}$ The original funding for Stage 1 was $\$ 600 \mathrm{~m}$ from Victorian Government; $\$ 300 \mathrm{~m}$ from the City of Melbourne retailers; and $\$ 100 \mathrm{~m}$ from irrigators (Department of Sus= tainability and Environment, 2009).

${ }^{4}$ One illustrative benefit of the NVIRP 2 scheme is reflected in the agreement of the Victorian Government to give approval for around $88 \mathrm{GL}$ of water trades from previous Commonwealth tender rounds originally blocked by Victoria's $4 \%$ limit on water traded out of a catchment district (DSE, 2009).

\section{An issues summary: implications of Desalination for Australia and beyond}

The theme of the simulations underlying this paper is that the conjunction of evolving water markets and reverse osmosis technology has set the stage for water constraints being relaxed in countries with coastal access and strong water institutions and networks. Agricultural and industrial sectors are now capable of responsibly using far more water for economic production and settlements of population. The result is, for water in all its forms to become a far more positive force for growth rather than the barrier to economic development that so many assume.

\subsection{The value of water}

Water, being valued far more in its absence than in its abundance, creates valuation and cost problems, and perceived policy dilemmas. The sense that water is "free" from nature leads to pressure decision-makers to price water at near zero, which can create longterm scarcity. Prices need to reflect potential scarcity 
as well as cost. Treating water as a scarce economic commodity-with designations of tradable rights, shares, pricing and allocation rules-is needed to remove water as a constraint on economic development. The tables of water prices globally, ${ }^{15}$ show affluent countries with high prices and generally sound incentives to invest and conserve. In comparison, low prices in very poor countries mean their utilities can-

10 not afford to catch, connect or treat water appropriately. Countries such as India, overwhelmed or politically unable to reverse the culture of a free or "social" status of water, price water so low that it is wasted in use and under-produced, with inadequate funds for new investment and supplies.

Water asset management is typically vested initially in government entities and engineering utilities that do not always apply sound incentive regimes for production, distribution or consumption. This creates more "dead capital", to use the terminology of Hernando de Soto [13], and so decades of scarce savings in water infrastructure are often wasted. The resulting losses to public health, life expectancy and capacity for food production mean that under-pricing water devalues the economic system, prevents efficient capital management and accumulation, and stifles well-being and economic growth.

Countries charging substantial amounts per cubic metre of water are typically affluent, with charges reflecting both scarcity value and the fact that people are willing to pay for water security. The resulting value of water also provides access to it, a feasible tax base for funding more than water utilities. While the preferred structure of access and usage charges for water is a matter for another paper, the point is clear. Under-pricing water makes economies and societies underperform, and in many cases it is a principal cause of poverty. Further, potential access to desalination makes the cost of price suppression policies even higher.

\subsection{Market and government failure in water sectors}

To see the potential of desalination, we first look beyond water to general economic performance. In particular, to the efficiency of energy generation needed to pump water through membranes, and the willingness of farmers, other labour and capital to play key roles in expanding the possibilities for water and its users in the desalination age. However, most important in many eyes is the governance of water, often clouded by poorly allocated or non-exchangeable water rights, allocations and pricing. As documented

\footnotetext{
${ }^{15}$ See for example: Global Water Intelligence (annually).
}

by Australia's Productivity Commission and many other reports Australia, and particularly Victoria, has pioneered the definition and vesting of water entitlements and rights, and the trading of these rights and allocations.

At the frontier of water technology very cheap sensors enable the "vectoring" of water stocks, flows and quality. Remote computers can automatically allocate or stop releasing water to particular crops and areas, such as stopping or adjusting when it rains. ${ }^{16}$ While the transition to smart systems and exploring change has its opponents, mainly because of uncertainties and politics, it is undeniable that the IT revolution and water trading and reforms-including desalinationwork well together across a market helped by a grid.

Australia has been leading with institutional arrangements for vesting and trading water entitlements and allocations, moving away from having water businesses run largely by engineering utilities and government agencies, but with government agencies continuing to have health, technical, regulatory and governance roles. Desalinated water can now serve as "insurance water", with a higher cost but high reliability of supply. Moving to vesting and trading, and desalination "insurance", improves the quality and security of water markets.

Although water insurance via desalination is now available in Australian metropolitan cities, we remain far from a "markets-can-fix-it" view. Government-authorised agencies continue to have roles, not least to vest and enforce water rights and secure their tradability in many cases. But the trading and pricing of water and resulting crop and industrial substitution has become a market phenomenon, with huge potential for adding value via premium and timely production and export.

\subsubsection{Australian water markets: tradable bulk water supply}

In the area of water markets and trading, the Australian experience has been positive and instructive. Economic fluctuations are less in agricultural areas than they would have been without water reforms, trading and pricing. What Australia can demonstrate, in the context of the recent drought, is just how

\footnotetext{
${ }^{16}$ The irrigation schemes such as on the Goulburn River, have computer and wirelessly managed irrigation gates (in their thousands) allocating water as technically required by gate, and as economic value of crops and grazing may dictate [14]. For illustrations of new wireless technology in irrigation see: http://www.rubiconwater.com/catalogue/ automation/network-control-solution.
} 
valued our market instruments and institutions for water are. The quality of economic governance and the surrounding infrastructure that accompany water supply networks determine whether desalination can be part of the bigger picture. In dry but ocean-rich countries, desalination can be the newly productive and risk-reducing link between people, the economy and water supply.

Over centuries irrigation has increasingly moved water to and between users. In Australia since the late nineteenth century, moving water has changed the scope of population, trade and settlement. While thousands of years behind Africa, the Middle East, Peru and Asia, Australia pioneered the expanded irrigation settlements following Alfred Deakin's engagement as Commissioner for Public Works and Water Supply in Victoria after 1883. His importation of the Chaffey brothers (and ascent to Prime Ministership of the new federation of Australia) saw the movement of water to people as a key to economic development. Over a century later, farm productivity rises through increasingly efficient irrigation systems, technology-based agriculture and animal husbandry-all despite restrictions in the cities, and political constraints on pricing and trading of water.

This brings us to the discussion of desalination and the Victorian water grid. The increasingly clear benefits of desalination (with its invariance to rainfall) are driven by the real (high and rising) land price, the difficulty of environmental approval for new dams, the political restrictions on pipelines between catchments, and the extreme inefficiency of stormwater and tank catchment systems as bulk suppliers.

In Victoria, new dam sites were identified and evaluated with a 100 year forward perspective [15], reviewed by consultants in 2004, and then used in the Central Water Strategy released in late 2006 [16]. Up to five sites were examined ranging in yield from about 40Gls to $150 \mathrm{Gls}$. The largest site was on the Mitchell River, with the others generally in central/ eastern Victoria-not far from the Thomson River catchment area.

While thorough business cases were not prepared, costs were expected to be comparable to other next best options; however, they did not include the opportunity cost of the catchments needed to yield the water.

Despite these and other evaluations and pressures, new large reservoirs have not been built in Australia for many years. Political and environmental factors are very significant and affect approvals, costs, timescales and deliverability. A desalination plant or pipelines (accompanied by contractual purchase of water and other harvesting agreements), while accruing some angst, are far more certain in terms of cost, deliverability and yield.

Even if approved, a new dam site in Victoria would be located in conservation land areas. It could take several years to obtain State and Commonwealth environmental and water approvals, which would probably still be constructed in a hostile environment. As a result, the potential yields (250-300 GLs) of possible new dam sites are modest in size as well as a source of uncertainty, particularly when urban systems are running down because of drought.

\subsubsection{Water restrictions}

Does desalination spell the demise of water restrictions as well as new dams and many tanks? The short answer should be yes! As the drought unfolded and catchment levels diminished, Australian state governments responded to these shortages through mandatory and increasingly tough restrictions, penalising gardens, parks, residential and other water users.

The cost of restrictions is large (such as outlays on $\$ 1,000-\$ 4,000$ household tanks) but heavily subjective. ${ }^{17}$ One way to quantify these restrictions in light of subsequent desalination decisions is to take a modest estimate of the cost of water restrictions, say a dollar a week or $\$ 50$ per year (which in Australia is less than a quarter of $1 \%$ of per capita income). Applied to three million people (half the Victorian population) this cost adds to $\$ 150$ million-enough to finance the interest at $6 \%$ on a $\$ 2.5$ billion desalination plant. This means the cost of water restrictions in the eastern states of Australia could be judged as expensive relative to the much criticised investment in desalination. When the costs of water restrictions are expressed in this way, it becomes understandable that all five mainland capitals installed sizable desalination plants as the drought started to exceed historical records. Those investments mean water restrictions in those cities can now be abolished and replaced by moderate pricing structures.

\subsubsection{Water security and water securities: a full portfolio approach to water supply and Desalination?}

One way of viewing the dilemma facing water bureaucrats and politicians associated with the Millen-

\footnotetext{
${ }^{17}$ The Productivity Commission [17] stated that “... the costs to consumers and the community have been large. Water restrictions are likely to have cost in excess of a billion dollars per year (nationally) from the lost value of consumption alone. Inefficient supply augmentation in Melbourne and Perth, for example, could cost consumers and communities up to $\$ 4.2$ billion over 20 years."
} 
Table 1

AQ15 A Summary of Australian Desalination investments, ${ }^{\text {a }}$ 2006-2012

\begin{tabular}{|c|c|c|c|c|c|}
\hline $\begin{array}{l}\text { Location } \\
\text { (project) }\end{array}$ & $\begin{array}{l}\text { Initial } \\
\text { investment } t^{b} \\
\$ \mathrm{~m}\end{array}$ & $\begin{array}{l}\text { Capacity } \\
\text { GL/pa }\end{array}$ & $\begin{array}{l}\text { Maximum } \\
\text { expandable capacity } \\
\text { GL/pa }\end{array}$ & $\begin{array}{l}\text { Initial (and expandable capacity as a \% } \\
\text { total in 2009-2010) } \\
\%\end{array}$ & $\begin{array}{l}\text { Completion } \\
\text { date }\end{array}$ \\
\hline $\begin{array}{l}\text { Sydney } \\
\text { (Kurnell) }\end{array}$ & 1,890 & 90 & 180 & $18(36)$ & 2010 \\
\hline $\begin{array}{l}\text { Melbourne } \\
\text { (Wonthaggi) }\end{array}$ & 3,500 & 150 & Up to 200 & $43(57)$ & 2012 \\
\hline $\begin{array}{l}\text { SE Queensland } \\
\text { (Tugun) }\end{array}$ & 1,200 & 49 & & 25 & 2009 \\
\hline $\begin{array}{l}\text { Adelaide (Port } \\
\text { Stanvac) }\end{array}$ & 1,830 & 100 & & 80 & 2012 \\
\hline Perth (Kwinana) & 387 & 45 & & 18 & 2006 \\
\hline $\begin{array}{l}\text { Perth } \\
\text { (Binningup) }\end{array}$ & 1,400 & 100 & & 40 & 2012 \\
\hline
\end{tabular}

Source: Ref. [17].

${ }^{a}$ Costs were incurred in different years, therefore are not precisely comparable; with construction costs rising over this period associated with the minerals sector investment boom.

nium Drought is that they pre-judged the optimal mix of bulk water supply and failed to allow for more trading and pipeline-based solutions in Melbourne, and to some extent in Sydney and Brisbane. By calling

5 for tenders for an amount of water supply from a specified technology, they could have allowed the market to decide on the technical and efficient means to deliver that amount and mix of water. Such a tender would have required the use of contracts with fea10 tures such as forward commitments of trading, bulk water mixing, pricing and other financial incentivedriven supply. Such a business-like approach would not fix on single technologies, regions and time, for large savings, but behave like any other market. While

15 the desalination decisions would, on our estimates, have survived, the scale and timing may have changed.

An analysis of how people could be encouraged to economise and trade water would have revealed income opportunities from importing and exporting water:

(a) through a piped water supply from a water abundant area;

(b) from a secure desalination plant that guarantees water at a ceiling price and

(c) using tertiary-treated recycled wastewater for those willing to pay to connect to this "new water" through separate pipes, as in Singapore.

Private companies could have assembled a portfolio of commitments to supply water by date and vol- ume, with Melbourne Water acting as the wholesale agency.

Rather than offer the full range of new bulk waters, Melbourne Water and the Victorian Government committed public resources to end the drought of metropolitan supply by investing in particular technologies; desalination and building the North-South Pipeline from near Yea on the Goulburn River to the Sugarloaf Reservoir near Melbourne. Disagreement on many aspects of the system is, in part, because trading, pricing and market compensation were restricted, precluding shared solutions.

The real question is why water demands are so rarely supplied using market instruments, when logic favours mutually beneficial trading arrangements. The evidence from other jurisdictions globally is abundant. Preventing the use of markets, trading and prices reduces the wealth of those with water rights and hurts those without, particularly in drought. The scope to potentially overcompensate losers can readily be established. The problem is whether political promises are delivered.

The next section discusses how water and liquidity benefit from the disciplines of portfolio theory and management.

\subsection{Optimal portfolio management}

Desalination illustrates that water has become remarkably like other liquid capital. Those with a demand for water can increasingly buy, borrow or invest in as much water as they like, at a price applicable to their risk level as judged by financial water 
Table 2

Melbourne Water Storage Levels, 1 August 2006-2010

\begin{tabular}{ll}
\hline Year & Storage levels on 1st August (as a \% of total system capacity) \\
\hline 2010 & 36.0 \\
2009 & 27.1 \\
2008 & 30.6 \\
2007 & 35.9 \\
2006 & 47.3 \\
\hline
\end{tabular}

Source: Bureau of meteorology, web site www.water.bom.gov.au.

markets. The water market has conditions akin to the market for financial liquidity; it offers a portfolio of distinct choices with differing risks, technologies, costs and returns. As the components of water supply have differing concepts and dimensions of risk-probabilistically far more complex than variances and co-variances-there is scope for packaging water deals. ${ }^{18}$

The problem is that unlike the simplistic but powerful mean-variance models, the potential states of water supply-by location, time, quality, storability, tradability and use-are as varied as all the states of historical and future uncertainty, be they economic, financial, climatic or environmental.

Unlike financial portfolio traders, water traders need also to address climate, time and weather. However, similar to financial traders, water traders do face the trade-off between risk and return (or cost) at the core of the portfolio and desalination decision. We now have bulk water supplies in the form of water assets across the grid with zero or weakly correlated yields, given that desalination and recycling treatment plants are rainfall-independent. This delivers new scope for communities to choose and pay for their preferred mix of water supply and security.

The analogy to financial investments is clear-it makes sense to combine technologies in different ways over time as nature varies the inflows and offsets. If industrial consumers can find water assets that are independent or imperfectly correlated in yield flows, then investors obtain the weighted average expected yield or cost, but at a lower level of portfolio risk

\footnotetext{
${ }^{18} \mathrm{~A}$ recent mathematical finance paper analysing a portfolio approach to water supply is Leroux and Martin [18]. This interesting paper strangely finds in favour of recycled water and against desalination, in line with some political opinions, but ignoring pipeline access and water trading. A problem with recycled water and particularly stormwater is perceived health risks (dead possums and rats in drains), community lack of acceptance of drinking what had been waste and stormwater, and the fact stormwater is correlated with rainfall, has low economies of scale and is generally viewed as not scalable in useful ways, compared with desalination.
}

because of offsetting or independent variations in yield, as in financial portfolio risk offsets. One implication is that simple water cost comparisons-such as short- or long-run, average or marginal-constitute incomplete information for risk-averse consumers and governments who highly value security and health, and for whom water costs are usually small in relation to income.

In the case of water supply, the portfolio can be simplified (see Fig. 4) by considering the basic case of a choice of:

(a) rainfall-dependent catchments-dams, pipelines, wells or river water and

(b) rainfall-independent methods-desalination, recycled water and stormwater plants.

A more complete model would estimate the expected unit costs and variance and co-variance across the alternative mixes.

This all suggests that the classic Tobin-Markowitz models of portfolio choice under uncertainty $[19,20]$ are as relevant to water supply as to financial portfolios of assets with differing risk and return profiles.

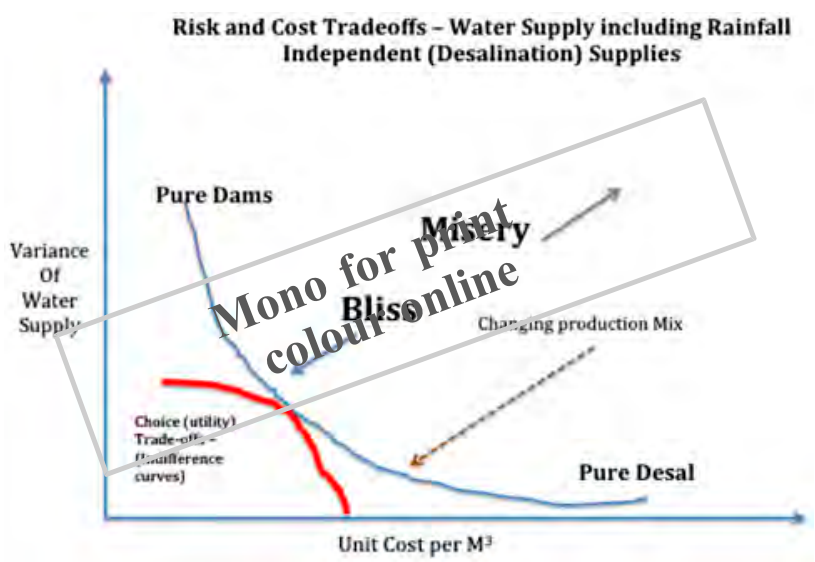

Fig. 4. Risk and cost trade-offs under a portfolio approach to water supply. 
In this approach, the higher cost of desalinated water does not mean it should be excluded from an efficient water supply mix as it has attractive riskreducing dimensions. As overall supply uncertainty is reduced with desalination in the mix, and given that consumers will trade-off some cost savings for increased security, the portfolio model suggests a useful analytical approach. Over time, the net costs from desalination plants will rise more slowly than for other water sources because of the effectively infinite bulk supply of ocean water relative to growing scarcity of land suitable for catchments. While the pumping and energy costs of desalination may rise, they are constrained by solar and other renewable technologies and falling battery costs.

\section{Modelling the Desalination plant within the Victorian water grid}

What follows is an explanation of how we can adapt a model, typical of that used in control centres for bulk water supply, to optimise water distribution across a supply and distribution grid. The model is augmented with economic parameters that influence demand and supply. (More detail on the model is available in Sahin et al, 2014 and from the authors).

The model reflects data on catchments and dams and, in subsequent versions and applications, river pipelines. Key inputs are capital and operating costs,

30 plus energy costs and pipeline costs of pumping and treatment. The control systems are augmented using Vensim $^{\mathrm{TM}}$ from Ventana Systems in Harvard, Massachusetts. The model is augmented by adding economic variables, such as retail tariffs, that respond to step downwards in catchment levels-so-called trigger levels. In turn, those triggers are security measures or the ratio of storages to demand levels where demand is measured conventionally as being influenced by normal usage patterns, population and economic growth.

We also look at the present value of capital and operating costs, with a view to computing relative discounted costs at differing discount rates. Most crucially, we study how investments would perform over a 100-year cycle of rainfall and inflows, based on actual Bureau of Meteorology data on water inflows to catchments. These data are also used in separate Monte Carlo studies to simulate other risks.

\subsection{The augmented systems dynamic model [21,22]}

To-date there have been no suitable or comprehensive life-cycle approaches to model city water balances that incorporate economic feedbacks, such as tariff adjustment, which can in turn create a financing capacity for investment responses to low catchment levels (such as desalination) and reveal significant policy implications for water planners. This project addresses the gap, and presents sections of a broader system dynamics model that augments the usual water utility representation of the physical linkages and water grids that can accommodate desalination plants, pipelines and rivers. At this stage the focus is on differing investments in dams and desalination plants. Pipelines from other river systems (such as the Goulburn in Melbourne's case) are currently not linked in. Demand is modified by combined assumptions of drought related tariffs and restrictions.

Tariffs in some runs of the model are reset in association with drought and responses are modelled in terms of reduced consumption and increased revenue of the utility, depending on the elasticity's of demand responses to higher tariffs (short- and longterm), while also allowing for effects from any transitional restrictions.

The key point is that augmented water supply schemes (i.e. desalination or large-scale advanced recycling plants) complement and potentially compete with the rain-dependent (i.e. dams or storm water treatment) sources in the region. Desalination acts as water insurance over the longer term, since it is expandable in relatively short timeframes at a price, independent of rainfall given the virtual infinity of seawater supply. The study also shows how an alternative temporary drought-pricing regime (i.e. water prices elevated above the base level when supply is scarce) not only defers costly bulk supply infrastructure but actually generates greater price stability than traditional pricing approaches.

The developed model has implications for water supply infrastructure planners seeking to justify, plan and finance both rain-dependent and rainindependent bulk water supply infrastructure to significantly lower the frequency and severity of water insecurity events. Interestingly, the model shows that a mixture of tariff and desalination plant adjustments to the grid will lower the long-run marginal cost of water by reducing dependence on expensive new dams.

Strength of this approach is that the sensitivity to baseline assumptions can be explored. For example:

(1) tariffs can be varied upwards in a drought;

(2) a water security index is used as an investment and tariff trigger when storage levels fall and 
(3) the relative cost escalation of catchment and dams to reverse osmosis desalination plants is explored, as they influence the time profile of capital and unit water costs within this dynamic model over a 100 year simulation cycle.

Sensitivity to discount rates, population and demand factors, and the advantages of modular desalination plants are also noted.

\subsubsection{Scarcity and drought-based pricing of water}

An important behavioural assumption is a scarcitybased pricing regime, offering scope in a drought to temporarily escalate (e.g. double), volumetric charges. A limited volume could be exempt for people on low incomes. If, for example, the price elasticity of demand
for water is minus $20 \%$, when tariffs double demand drops $20 \%$ and sales revenue goes up to $80 \%$. The pressure for a new water source diminishes, and may disappear if the rains return as they do over cycles (e.g. when rains follow drought when an El Niño event is replaced by a La Niña Pacific oscillation event). ${ }^{19}$

To the extent that the drought continues and tariffs increase, the utilities will have gained revenue to fund desalination plants or dams. Timing becomes important, with the rapid "de-mothballing" costs of idle desalination plants, or running at less than capacity, being a relatively small price to pay compared with

\footnotetext{
${ }^{19}$ See Bureau of Meteorology [23]. To quote from this reference to the Australian Bureau of Meteorology web site: "El Niño and La Niña events are a natural part of the global climate system. They occur when the Pacific Ocean and the atmosphere above it change from their neutral ('nor$\mathrm{mal}^{\prime}$ ) state for several seasons. El Niño events are associated with a warming of the central and eastern tropical Pacific, while La Niña events are the reverse, with a sustained cooling of these same areas.These changes in the Pacific Ocean and its overlying atmosphere occur in a cycle known as the El Niño-Southern Oscillation (ENSO). The atmosphere and ocean interact, reinforcing each other and creating a 'feedback loop' which amplifies small changes in the state of the ocean into an ENSO event. When it is clear that the ocean and atmosphere are fully coupled an ENSO event is considered established.Even in a neutral state, temperatures in the Pacific Ocean vary from east to west-for example, the western Pacific 'warm pool' in the tropical Pacific has some of the warmest largescale ocean temperatures in the world. During an ENSO event, ocean temperatures become warmer than usual or cooler than usual at different locations, which are reflected in ocean temperature gradients. The most important driver of ENSO is these temperature gradients across the Pacific, both at the surface and below the surface, particularly at the thermocline."
}

new water restrictions or sacrificing land and capital to provide a new dam.

\subsubsection{Water security index - as a trigger for tariffs and investment}

The water security index reflects the ratio of water storage to annual usage and the storage buffer required against low rainfall years. Clearly, desalination plant capacity reduces the need for dams and their land-intensive catchments. As a result, assumptions about tariffs and trends in the relative prices of land, plant and energy costs, and differing water treatments and pipeline costs, inform decisions about preferred options over time, given rainfall, population and economic uncertainties.

4.1.3. Land costs as a discriminant between desalination and dams

The presence of modular and expandable desalination plants means there is less reliance on dams in the context of fluctuating inflows. Desalination offers roughly flat (expansion) cost curves and duplication capacity given adequate oceans, whereas dams have steeply increasing costs due to relatively extreme scarcity of suitable land. Dams need catchments and rivers, and more extensive community hearings and approval than much more compact desalination plants. With this in mind, the study explores how the advantages or otherwise of desalination plants are affected by increase in population and land costs.

The results below use graphs to illustrate the cost variations from the varying assumptions and feedback loops of the model as it stands in May $2014^{20}$. At this stage, the graphs reflect current political realities restricting inter-basin water transfers now available through pipelines constructed by the previous government. We do not depict, therefore, the sizable potential expansion of water trading in Victoria using the North-South or Sugarloaf Pipeline from the Goulburn River and the Eildon Dam. These sources offer major additional and extremely reliable supply for many years to come, and if drought conditions return. Just as Adelaide was "saved" in water supply terms during the drought by the Mannum-Adelaide pipeline (when $91 \%$ of water supply was provided by the River Murray in 2006-2007 [1]), future low rainfall periods should see water trading expand dramatically in

\footnotetext{
${ }^{20}$ Readers seeking detailed summaries of the model, parameters and schematics in Vensim ${ }^{\mathrm{TM}}$ format are invited to contact the authors for greater detail, and also to see $\mathrm{Sa}-$ hin et al, 2014.
} 
Victoria and across southeast Australia based on these interconnected supplies and grid., and differing water values by location.

The model builds on the costs of adding desalination to existing sources and networks. The real challenge in the project and model is integrating desalinated water into grids of other supplies, and minimising the costs of periodic mothballing of plants when other supplies are abundant and cheap. The effectiveness of a portfolio increases, the less positive the correlation of water supplies across the component sources, and the larger the base level of secure supply

15 through rainfall-independent desalination. If supplies are adequate, the operating costs of desalination are of course generally higher than river sources.

\subsection{Results}

The charts and tables below draw on preliminary results from a draft paper, Exploring the sensitivity of water modelling: a case study of future water supply augmentation options for an Australian city, Scarborough, Sahin 2014, Porter, Stewart and Downie, mimeo, Deakin University, March 2014. Actual or modified rainfall and inflow data is used from the Australian Bureau of Meteorology to see what levels of dams, desalination plants and tariff triggers and escalations do to average costs and the capacity to avoid restrictions, for example, should rainfall patterns be repeated. Results are interpreted and summarised in general terms below. Later work will vary rainfall and inflow assumptions with Monte Carlo drought studies, treated waste (or "purple") water usage, along with tariff, cost and technology data for dams and desalination, and crucially

35 the use of pipelines from rivers and savings from optimised irrigation systems.

By turning attention to forward planning of Melbourne's water supply options, this systems-augmented model suggests that desalination provides a far lower cost option for water security over the next 100 years than dams or restrictions. These costs fall even more as land costs rise relative to reverse osmosis desalination costs. Based on the model, new dams should phase out due to cost considerations, and desa45 lination should expand substantially over the next century in a modular way. However, the growth of desalination will moderate if governments and rural interests become more interested in generating income by trading river water and adjusting crops and graz-

50 ing to suit market conditions. The current model also accepts the current political restriction of using water from the Goulburn and Eildon Dam, for example, to serve metropolitan Melbourne (Our Adelaide desalination paper, forthcoming, and updates of this paper will add politically constrained river pipelines to the portfolio mix).

\subsubsection{Additional storage and time preference}

Fig. 5 shows Melbourne's additional water storage capacity requirements for the next 100 years, based on a repeat of the last 100 years of rainfall and inflows. The additional storage capacity reflects the water security index assumed. Simulations use two levels:

(1) a BLUE level of security equal to three-year's capacity to meet demand and

(2) a RED level of security equal to four-year's demand.

This sensitivity is illustrated in Fig. 5 based on the 2006 water demand level (per person). If the 2013 water demand figure is used, this ratio would be 4 , which is a more realistic assumption. Analysis indicates that Melbourne will require investment in additional water capacity within 20 years.

When comparing the cost of supply alternatives, using a $1.5 \%$ discount rate, the comparable net present value of investment costs over the 100-year period are $\$ 36.3$ billion for dam costs and $\$ 22.4$ billion for desalination costs (Fig. 6). This illustrates clearly that desalination is a viable and preferable long-term component of Melbourne' future water portfolio. This argument becomes dramatically stronger when considering issues such as land availability for catchments and the increasing variability of rain-dependent supply options.

\section{Assumptions for the simulation of desalination versus} dams are:

Catchment escalation cost increase pa $=1 \%$

Population growth rate $=1.25 \%$

New desalination construction when needed $=$ YES

New desalination plant size $=50 \mathrm{GL}$

Water Security Index = Varying

Discount rate $=1.5 \%$

\subsubsection{Discount rates and long-term comparison of} social infrastructure costs

The real discount rates applicable to normal private sector risks are typically around $10 \%$; indeed the Australian Treasury applies $7 \%$ for high-risk infrastructure. The reason low rate such as 1.5 or $2.5 \%$ are applicable to intergenerational public infrastructure is because by applying a high rate over a long time 


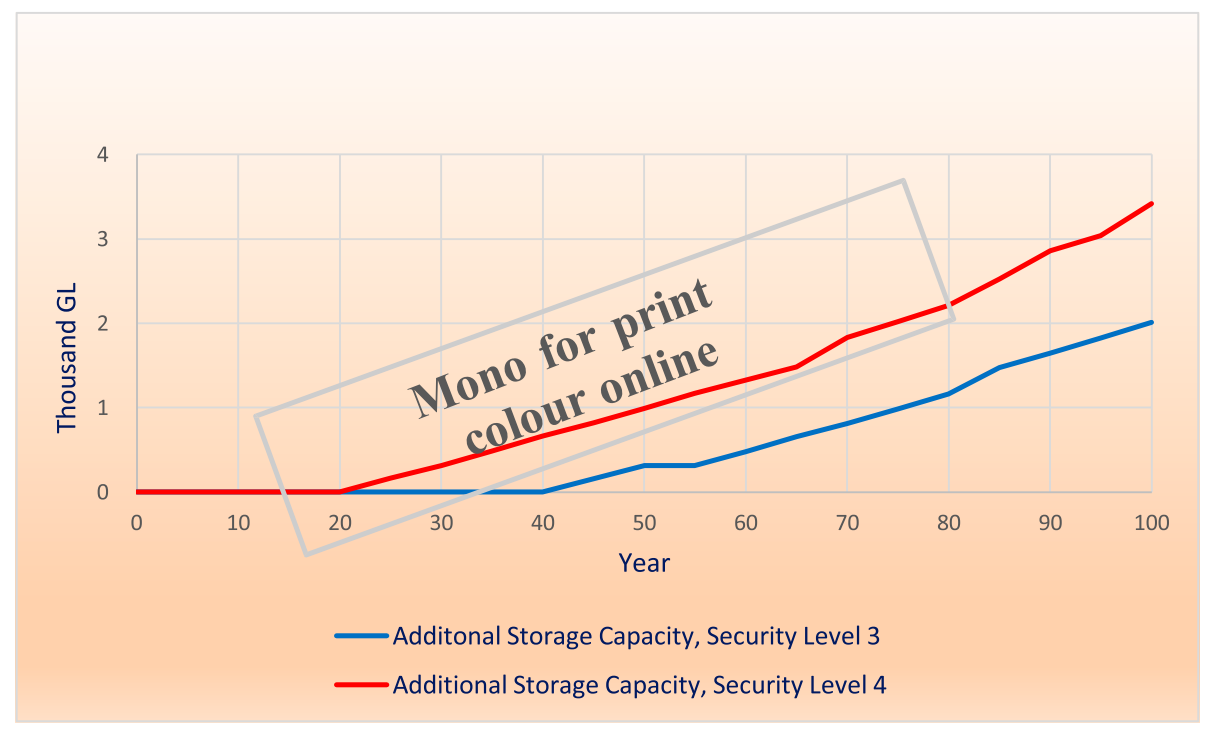

Fig. 5. Additional storage capacity to maintain water security.

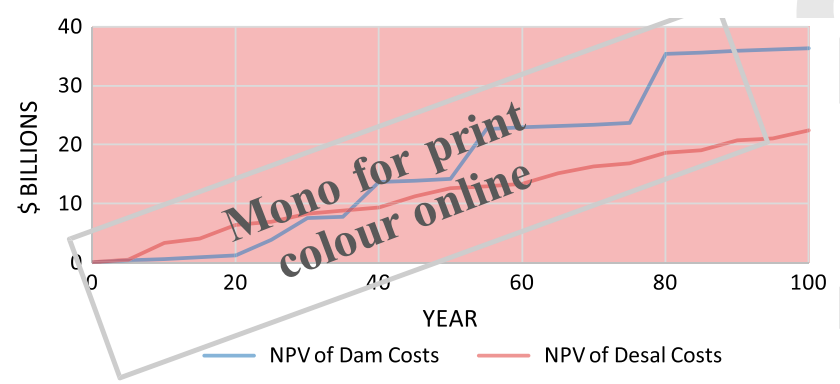

Fig. 6. Comparison of water supply augmentation costs with $1.5 \%$ social discount rate.

frame significantly overvalues the asset in today's terms. For example, at $7 \%$ a dam today is roughly 16 times the discounted value of the same asset in 40 years' time (at 7\%, an asset doubles roughly every 10 years). ${ }^{21}$

\footnotetext{
${ }^{21}$ Treating all generations exactly equally implies a discount rate of zero. If per capita growth is assumed to be positive, our children and their children will be on average better off than we are today. Considerations of equity as well as capital markets imply that future economic values should be discounted when considering investments and compensation over time. Choosing discount rates such as $7 \%$ is not kind to children or grandchildren in terms of providing future infrastructure. But not discounting at all penalises earlier generations who will not share in technology and income advances that are likely to occur [24]. This is a controversial topic, not least in relation to climate change and related issues such as water supply for future generations.
}

\subsubsection{Land costs and the choice between desalination and dams}

Fig. 7 summarises the escalation of dam costs relative to desalination over the century, as the land costs rise at $1 \%$ pa relative to desalination plant costs. The present value of dam costs, assuming the discount rate of $1.5 \%$, is about $\$ 45$ billion greater than for more frequent investment in smaller desalination modules. While the relative land intensity and escalation of land prices is somewhat arbitrary, a number of experts consulted on the scope for new dams to serve Melbourne were sceptical of their community and political feasibility despite the significant population and economic growth predicted for Australia and Melbourne. ${ }^{22}$

While there is a sound analytical case for comparing dams and desalination plants using low discount rates, it does not imply that companies risking shareholder capital should apply these rates. Capital markets will often find reasons given construction, union

${ }^{22}$ In the last 40 years, $89 \%$ of the growth in capitals occurred in the four largest cities (Sydney, Melbourne, Brisbane and Perth), with Perth and Brisbane more than doubling in population. Darwin had the highest growth rate $(191 \%)$ of all capital cities. In contrast, Hobart grew by $36 \%$. For city population data (see ABS, 2014).In terms of AQ10 absolute numbers, Sydney and Melbourne each grew by almost 1.7 million people between 1973 and 2013, although the overall growth rate for Melbourne was higher $(62 \%$ increase compared with 54\%). This reflects Melbourne's comparatively higher growth rates in recent years. If current trends prevail, Melbourne is projected to overtake Sydney to become Australia's largest capital city by 2053. 


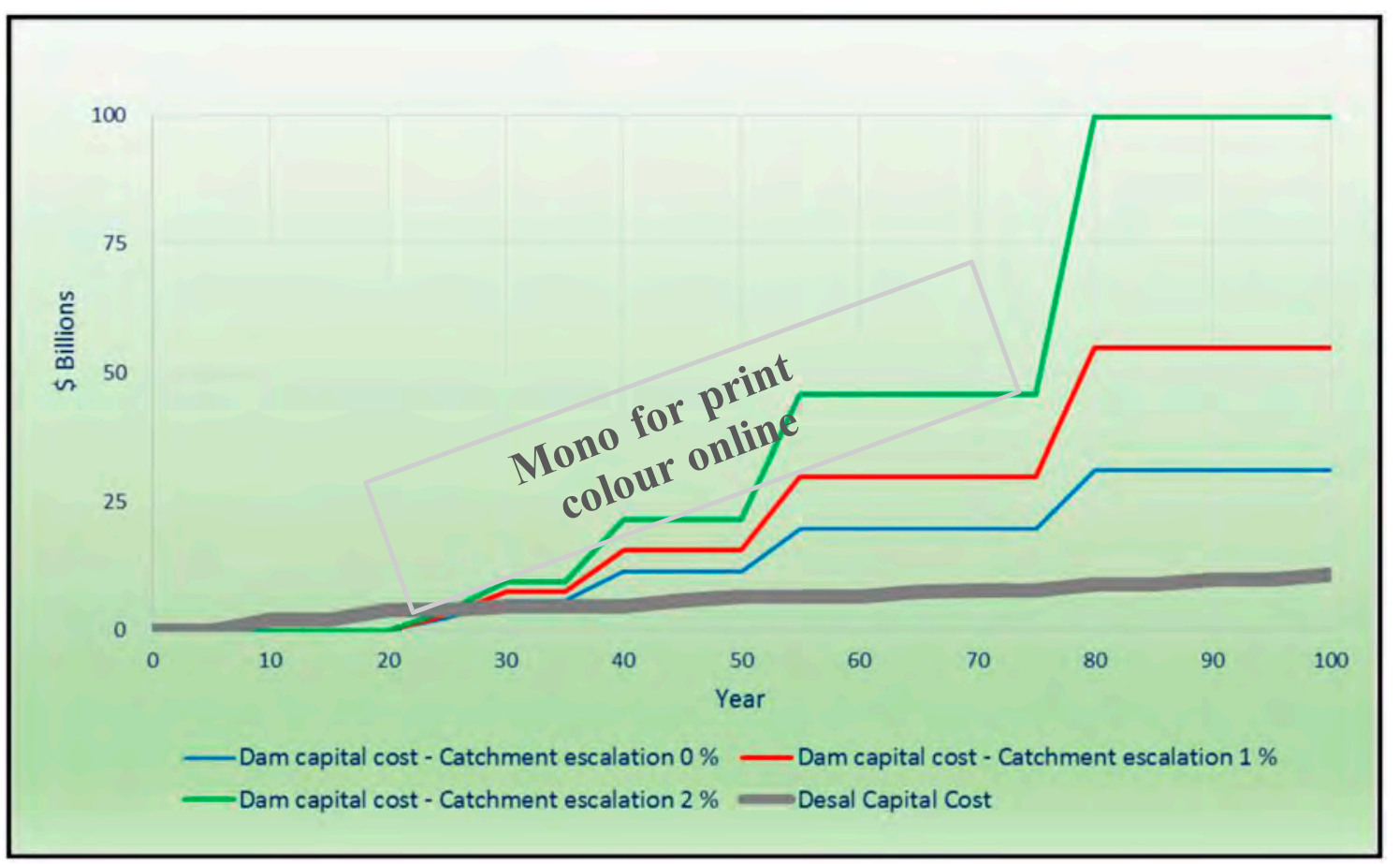

Fig. 7. Land price escalation impact: Desalination vs. dams.

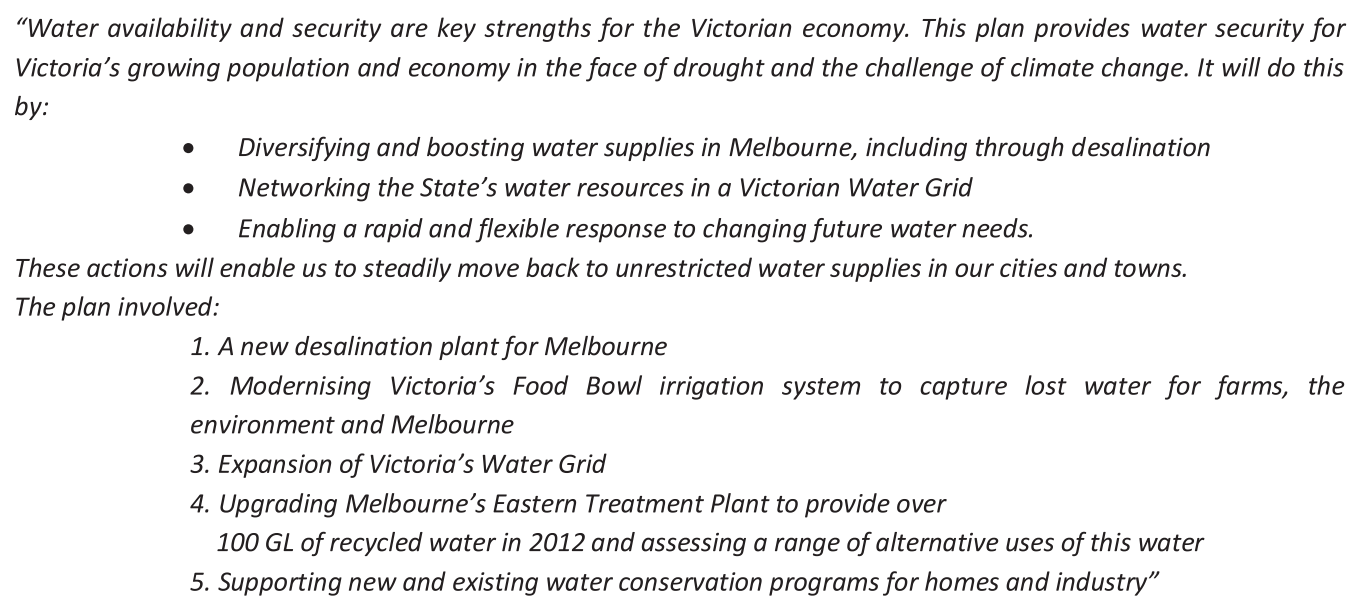

Extract 1. Our Water Our Future: The Next Stage of the Government's Water Plan, Government of Victoria, June 2007 [6].

and weather risks to apply rates in the $10-15 \%$ brackets. Governments take notice of such rates when evaluating private sector tenders by risk class. Also, in comparing government vs. private sector investments, governments investing public funds need to recognise the proven scope that political lobbies and sloppy analysis create for poor selection of projects-whether dams, desalination plants, subsidised insulation ("pink batts") or broadband. In general, governments should also apply similar discount rates to those in the private sector for each risk class-since the project may be a failure. The history of governments monopolising investment decisions is well discussed (see e.g. de Soto, op. cit., 1991). 


\section{Conclusion}

The major result from this simulation of rainfall, investment, population and pricing data and options is that desalination delivers lower long-term average costs than a reliance on dams, assisted by delaying the need for large scale dams.

The great feature of expanding desalination capacity relative to dams is that desalination provides a buffer of augmentable size, with two-year plus construction periods. Desalination delivers an expanded capacity to ride through increased rainfall volatility. Further, the consequences of any climate change and El Nino phenomena would be mitigated better by desalination and water trading than by dams.

Regardless, these results show that water demands and security needs can be met as the population and economy expand. Rainfall volatility and drought are surmountable challenges, with relatively affordable desalination enabling more settlements across Australia depending on distances from coastlines. While desalination has not yet been modelled in dry inland locations, a similar set of results apply independently of distance from coastline, but depending on physical productivity and incomes.

Adding drought-related tariffs to the simulations postpones both investment in desalination and dams, but does not change the fundamental preference for desalination which can be financed through these tariffs given dam and catchment cost increases.

Finally, choosing a higher security index of 4 as opposed to 3 (the ratio of storage to annual demand) brings forward the investment in both desalination plants and dams, and because of smaller units of expansion, generally places greater value on modular desalination capacity.

\section{References}

4] CSIRO, The Millennium Drought and 2010/11 Floods,
Vulnerability (Working Group ii), Climate Council of Australia, 2014.

[6] Department of Sustainability and Environment, Our Water Our Future the Next Stage of the Government's Water Plan, Department of Sustainability and Environment, Melbourne, 2007.

[7] J. Brumby, The Victorian Desalination Plant: Securing Victoria's Future, PowerPoint slides, presented at National Centre of Excellence in Desalination International Desalination Workshop, Melbourne, 2013. Available from: http://desalination.edu.au/wp-content/ uploads/2013/12/John-Brumby.pdf (accessed 21 July 2014).

[8] Melbourne Water, Water Catchments, Melbourne Water, 2014. Available from: http://www.melbourne water.com.au/whatwedo/supply-water/Water-catch ments/Pages/water-catchments.aspx (accessed 10 April 2014).

[9] S. Dundorf, J. MacHarg, B. Sessions, T. Seacord, Optimising Lower Energy Seawater Desalination, International Desalination Association World Congress, UAE, 2009, pp. 1-27.

[10] J. Langford, J. Briscoe, M.G. Porter, Creating Wealth from our Water, The Australian, 2010. Available from: http:/ / www.theaustralian.com.au/news/creatingwealth-from-our-water/story-fn6nj4ny-1225945844874 (accessed 10 April 2014).

[11] J. Briscoe, Submission to the Standing Committee on Legal and Constitutional Affairs of the Senate, 2011. Available from: http://aefweb.info/data/Briscoe\% 20submission $\% 20$ to $\% 20$ senate $\% 20$ inquiry $\% 20$ on $\%$ 20Water\%20Act.pdf (accessed 21 July 2014).

[12] Department of Environment and Primary Industries, Northern Victoria Irrigation Renewal Project Stage 2 Agreement, Department of Environment and Primary Industries, 2012. Available from: http://www.water. vic.gov.au/resources/news_items/archived-newsitems / 2011-news-items / nvirp-stage-2-fundingannouncement (accessed 21 July 2014).

[13] H. de Soto, The Mystery of Capital: Why Capitalism Triumphs in the West and Fails Everywhere Else, Basic Books, New York, NY, 2000.

[14] Department of Primary Industries, State of the ArtOn Irrigation Farms Edition 1, Department of Primary Industries, 2012. Available from: http://vro.depi.vic. gov.au/dpi/vro/vrosite.nsf/pages/lwm_state_art_irri gation_docs/\$FILE/Stateoftheart_edi tion1_web_tagged_final.pdf (accessed 10 April 2014).

[15] Department of Conservation and Environment, Water in Victoria: The Next 100 Years, Department of Conservation and Environment, Melbourne, 1991.

[16] Department of Sustainability and Environment, Sustainable Water Strategy: Central Region, Department of Sustainability and Environment, Melbourne, 2006.

[17] Productivity Commission, Australia's Urban Water Sector (Report No. 55), Canberra, 2011.

[18] A.D. Leroux, V. Martin, Optimal Portfolio Management of Urban Water, Working Paper, 2013.

[19] H.M. Markowitz, Portfolio Selection. J. Financ. 7(1) (1952) 77-91.

[20] J. Tobin, Liquidity preference as behavior towards risk, Rev. Econ. Stud. 25(2) (1958) 65-86.

[21] O. Sahin, R.A. Stewart, M.G. Porter, Paradigm shift to enhanced water supply planning through augmented CSIRO, 2011. Climate Council of Australia, Unpacking the Fifth Assessment Report: Impacts, Adaptation, and

5

65

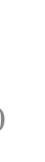


grids, scarcity pricing and adaptive factory water: A system dynamics approach, Environ. Model. Softw. (in press) 1-14.

[22] O. Sahin, R.S. Siems, R.A. Stewart, M.G. Porter, Water security through scarcity pricing and reverse osmosis: A system dynamics approach, J. Clean. Prod. (in press) 1-12.

[23] Bureau of Meteorology, What are El Niño and La Niña events?, Bureau of Meteorology, 2014b. Available from: http://www.bom.gov.au/climate/enso/his tory/ln-2010-12/ENSO-what.shtml (accessed 10 April 2014).

[24] K. Arrow, K. Cropper, M. Gollier, C. Groom, G. Heal, R. Newell, W. Nordhaus, R. Pindyck, W. Pizer, W. Portney, P. Sterner, R. Tol, M. Weitzman, How Should Benefits and Costs Be Discounted in an Intergenerational Context? The Views of an Expert Panel, Resources for the Future, Washington, DC, 2012.

[25] Melbourne Water, Water Storages: Water Report, Melbourne Water, 2013. Available from: http://www. melbournewater.com.au/content/water_storages/wat er_report/water_report.asp?bhcp=1 (accessed 10 April 2013).

[26] Bureau of Meteorology, Archive-Thirty-six-monthly rainfall deciles for Australia, Bureau of Meteorology, 2014a. Available from: http://www.bom.gov.au/jsp/ awap $/$ rain/archive.jsp?colour=colour $\&$ map $=$ decile $\&$ year $=2009 \&$ month $=6 \&$ period $=36$ month $\&$ area $=$ nat (accessed 21 July 2014).

[27] Frontier Economics, Review of Urban Water Entitlements in Australia: A Report Prepared for the Joint Steering Committee for Water Sensitive Cities, Melbourne, 2008.

[28] Melbourne Water, Weekly Water Update Archive, Melbourne Water, 2007. Available from: http://www mel bournewater.com.au/waterdata/waterstorages/Week ly-water-update/Pages/Weekly-water-update-archive. aspx (accessed 10 April 2014). 


\section{Appendix 1. Modelling}

Table A1 Baseline assumption for Melbourne water supply and demand ${ }^{23}$

\begin{tabular}{ll}
\hline Variable & Baseline assumption \\
\hline Population-current & 4.25 million \\
Population growth rate & Default $1.25 \%$ \\
Current water use-Litre per person per day & $250 \mathrm{~L} / \mathrm{p} / \mathrm{d}$ (150 residential and 100 non-residential) \\
Dam capacity-current & $1,812 \mathrm{GL}$ \\
Desal capacity p.a.-current & $150 \mathrm{GL}$ \\
Desal capital costs & $\$ 1.2 \mathrm{~b}$ \\
Desal operation cost & 0 to $182 \mathrm{~m}$ \\
Dam capital cost & $1.7 \mathrm{~b} / 100 \mathrm{GL}$ \\
Dam operation cost & $10 \mathrm{c}-30 \mathrm{c} / \mathrm{kL}$ \\
Model time bound & 100 year \\
Time interval of simulation & $1 / 4$ year \\
Water security index & Varying 1 to 6 \\
Discount rate & Default $=1.5-3.5 \%$ \\
Flow capacity p.a. of new desalination plant to be constructed & Default $50 \mathrm{GL}$ p.a. \\
Capacity of new dam to be constructed & $100 \mathrm{GL}$ \\
\hline
\end{tabular}

\footnotetext{
${ }^{23}$ The cost of a new dam with is assumed to be $\$ 1.7$ billion (Based on Traveston Crossing). Dam yield: 110 GL per annum; Dam height: 79.5 metres; Land needed: 2,900 hectares; Cost: Stage $1 \$ 1.7$ billion; Stage $2 \$ 250$ million. According to "Water supply options for Melbourne - An examination of costs and availabilities of new water", the cost of a new dam duplicating the Thomson Dam on the Mitchell River is $\$ 1.35$ billion based on a 2005 study by Sinclair Knight Merz (SKM) and released by the Government of Victoria (August 2008). The SKM study, completed in 2004, was not subject to open scrutiny by regulators or commercially informed parties. The study claimed that the present annual average recommended yields of $111 \mathrm{GL} /$ year might be reduced by climate change by $20 \%$ by 2050 . If such reduced levels of availability have any credibility, SKM suggests the need to plan for more additional capacity. The SKM study estimated capital costs for a dam on the Macalister, such as the Mitchell designed to be linked into the Thomson, would be \$398-694 million.
} 